\title{
Evaluation of applicability of thick E500 TMCP and F500W QT steel plates for Arctic service
}

\author{
Pavel Layus ${ }^{1 *} \mathbb{D}$, Paul Kah', Vladislav Ryabov² and Jukka Martikainen ${ }^{1}$
}

\begin{abstract}
Background: The paper presents a study of E500 TMCP European and F500W Russian Arctic shipbuilding thick steel plates. E500 steel plate (thermo-mechanically controlled process (TMCP), $25 \mathrm{~mm}$ thickness) and F500W steel plate (QT, 30 and $35 \mathrm{~mm}$ thickness) are designed for operation in Arctic conditions at temperatures as low as -40 and $-60{ }^{\circ} \mathrm{C}$, respectively.

Methods: The steels were evaluated in terms of base metal quality and welding performance. Welds and base metal were tested by methods described in International and Russian standards, namely the static tension test, Charpy V-notch impact test, drop weight test to determine nil-ductility transition (NDT) temperature, threepoint bending (Tkb) test, and crack tip opening displacement (CTOD) test. European E500 TMCP steel was evaluated according to the requirements of Russian standards; additionally, the research assesses the ability of E500 TMCP steel plates to meet the requirements of special tests required by the Russian Maritime Register of Shipping, such as Tkb and NDT tests.

Results: F500W QT obtains better results in special tests like NDT $\left(-100^{\circ} \mathrm{C}\right.$ is better than $\left.-65^{\circ} \mathrm{C}\right)$ and CTOD (CTOD $-40^{\circ} \mathrm{C}$ average $1.18 \mathrm{~mm}>0.41 \mathrm{~mm}$ ). Using quenching followed by high tempering enables possible operational temperatures down to $-70{ }^{\circ} \mathrm{C}$. However, the NDT test is required only in Russian standards. E500 steel base metal tests showed applicability based on criteria of the Charpy test at temperatures as low as $-85^{\circ} \mathrm{C}$; based on criteria of NDT at $-65^{\circ} \mathrm{C}$; based on Tkb criteria only at $-40{ }^{\circ} \mathrm{C}$; and CTOD test showed E500 applicability to as low as $-55^{\circ} \mathrm{C}$. E500 welding tests showed, that Charpy impact toughness values are limiting the use of MMA welds to $-20^{\circ} \mathrm{C}$, and FCAW and SAW welds can be utilized with some limitations at $-40{ }^{\circ} \mathrm{C}$. CTOD of the welded joint showed that E500 applicability at $-40^{\circ} \mathrm{C}$ is satisfactory just on the borderline of the standard requirements.
\end{abstract}

Conclusions: The test results showed fair performance for both the European and Russian steels. The steels were found to meet the requirements for Arctic application of both European and Russian standards.

Keywords: Shipbuilding, High-strength steels, Cold resistance, CTOD, NDT, Tkb, TMCP, QT, SAW, Welding, Thick plates

\section{Background}

Environmental conditions in the Arctic are extremely harsh, with low temperatures (down to $-70{ }^{\circ} \mathrm{C}$ ), ice sheet formation, long periods of darkness, strong winds, and remote locations. Consequently, the design of ships and offshore structures intended for Arctic service presents significant engineering challenges.

\footnotetext{
*Correspondence: pavel.layus@lut.fi

${ }^{1}$ Laboratory of Welding Technology, Lappeenranta University of Technology, Lappeenranta, Finland

Full list of author information is available at the end of the article
}

Due to the remoteness of Arctic locations, construction cost penalties increase tremendously with increased weight of construction materials and equipment and there is thus demand for lightweight structures and weight reduction in Arctic maritime vessels and installations. Ships and lightweight structures are usually made of high-strength steels, which allow use of thinner steel plates for the same load-bearing capacity. Thinner plates are beneficial for shipbuilding and structural applications as they make the welding process easier and cheaper. High-strength steels make it possible to design not only 
lightweight structures and ships but also simple structures with simple joint designs.

The most common high-strength steel types are thermo-mechanically controlled processed (TMCP) steel and quenched and tempered (QT) steel. TMCP is currently in the research spotlight because, for the same mechanical properties, TMCP steel has a lower carbon equivalent $\left(\mathrm{C}_{\text {eqv }}\right)$ than $\mathrm{QT}$ steel. The carbon equivalent level correlates with weldability; the lower the $C_{\text {eqv }}$, the better the weldability.

A small amount of research has been done on the applicability of TMCP and QT high-strength steels for the Arctic region. Lee et al. (2012) reviewed the use of TMCP steel SM570-TMCP in cold regions and concluded that selection of a suitable welding process is essential for utilization of TMCP steels in such environments. In other work, Yan et al. (2014) investigated the mechanical properties of QT S690 steel in Arctic conditions. Further work by Shin et al. (2006) focused on the fracture characteristics of TMCP and QT steels in Arctic conditions.

TMCP steel use is on the rise in many large-scale industrial applications, such as shipbuilding, steel structures, and transport. This paper evaluates thick Finnish TMCP E500 steel plate manufactured by Rautaruukki Oy and two Russian QT F500W steel plates manufactured by PAO Severstal. The two F500W steel plates differ by the billet from which they are made; one steel plate is manufactured from ingots and the other from slabs. Evaluation of the steels included mechanical and cold-resistance property assessment of base metal and welds. Joint experiments to determine the mechanical properties of F500W steel plates $(30$ and $35 \mathrm{~mm}$ ) and E500 steel plate $(25 \mathrm{~mm})$ were conducted as a part of the Arctic Technology Development project (Arctic Materials Technologies Development (Arctic Development)). According to specification, F500W steel can be used for Arctic applications at temperatures as low as $-60{ }^{\circ} \mathrm{C}$ (letter " $\mathrm{F}$ ") and has improved weldability (letter "W"). Steel E500 is designed for Arctic applications at temperatures as low as $-40{ }^{\circ} \mathrm{C}$ (letter "E") (GOST R 52927-2008). Comparison analysis of the two steel grades included chemical composition assessment, microstructure examination, mechanical properties tests, impact toughness tests at low temperatures, and special cold-resistance tests-the nil-ductility transition (NDT) temperature test, the three-point bending (Tkb) test, and the crack tip opening displacement (CTOD) test. Table 1 contains a complete list of the experiments conducted to test F500W and E500 steel plates' base metal and welded joint properties.

Specimens for the tests were cut from the steel plates using a water jet cutting machine. The water jet cutting method was selected to minimize heat input to the base
Table 1 List of experiments conducted to evaluate F500W and E500 steel plates

\begin{tabular}{ll}
\hline Base metal & Welded joints \\
\hline Chemical composition & Chemical composition \\
Microstructural analysis & Mechanical properties \\
Mechanical properties & Hardness measurement \\
Cold-resistant tests: & Cold-resistant tests: \\
- Charpy V-notch impact test & - Charpy V-notch impact test \\
- NDT test & - CTOD test \\
- Tkb test & \\
- CTOD test & \\
\hline
\end{tabular}

metal and to reduce waste metal during the cutting process. Tests were carried out according to International and Russian standards (GOST R 52927-2008; ASTM E208; GOST 9454-78; GOST 1497-84; GOST 14019 80; GOST 2999-75; ASTM E112 13; ASTM E1382 - 97 2999; GOST 5639 82; BS 7448-1:1991; ISO 15653 2010; Russian Maritime Register of Shipping et al. 2012; EN ISO 19902 2007; DNV OS B101 2009; DNV OS C401 2010; API RP2Z:2005). Standard requirements for Arctic application of E500 and F500W steel plates are listed in Table 2.

As can be seen from Table 2, the Russian classification societies currently have higher requirements for steels intended for Arctic service than European and American classification societies. In Russian standards, obligatory tests of the base metal include Tkb and NDT tests and there are more stringent requirements for the Charpy Vnotch impact test and CTOD test. Based on the results of the whole set of tests, an appropriate temperature $\mathrm{Td}$ (design temperature) is determined. Td indicates the temperature at which the steel can be used for the most critical and heavily loaded elements of hull structures and other Arctic applications (Gusev 2013).

\section{Methods \\ Base metal evaluation \\ Chemical composition}

Information on steel plate thickness, manufacturing method, grades, and chemical compositions was measured and is given in Table 3. The F500W steel plates (30 and $35 \mathrm{~mm}$ ) are made by QT method, and the E500 steel plate $(25 \mathrm{~mm})$ is made by TMCP. Therefore, E500 and F500W steel chemical composition is significantly different.

Russian RMRS standards (Russian Maritime Register of Shipping et al. 2012) and European standards (EN 10149 2) specify the maximum permissible percentage of sulfur and phosphorous in the chemical composition. For the analyzed high-strength steels, the maximum percentage should be below 0.005 and $0.01 \%$ for sulfur and phosphorous according to RMRS rules and below 0.025 and $0.015 \%$ for sulfur and phosphorous, respectively, 
Table 2 Standard requirements for E500 and F500 steels (GOST R 52927-2008; ASTM E208; GOST 9454-78; GOST 1497-84; GOST 14019 80; GOST 2999-75; ASTM E112 13; ASTM E1382 - 97 2999; GOST 5639 82; BS 7448-1:1991; ISO 15653 2010; Russian Maritime Register of Shipping et al. 2012; EN ISO 19902 2007; DNV OS B101 2009; DNV OS C401 2010; API RP2Z:2005)

\begin{tabular}{|c|c|c|c|c|c|c|c|c|}
\hline \multirow[t]{2}{*}{ Classification society } & \multirow[t]{2}{*}{$\sigma_{\mathrm{t}}, \mathrm{MPa}$} & \multirow[t]{2}{*}{$\sigma_{0.2}, \mathrm{MPa}$} & \multirow[t]{2}{*}{$\delta_{5}, \%$} & \multirow{2}{*}{$\begin{array}{l}\text { Impact energy, } \\
\mathrm{KV}^{-60} \text { (for grade } \mathrm{F} \text { ) } \\
\text { and } \mathrm{KV}^{-40} \\
\text { (for grade } \mathrm{E}), \mathrm{J}^{\mathrm{a}}\end{array}$} & \multirow{2}{*}{$\begin{array}{l}\text { Temperature of } \\
\text { ductile-to-brittle } \\
\text { transition, } T_{\mathrm{KB}}^{\mathrm{b}},{ }^{\circ} \mathrm{C}\end{array}$} & \multirow{2}{*}{$\begin{array}{l}\text { CTOD of plates up to } \\
50 \mathrm{~mm} \text { thickness at }-60{ }^{\circ} \mathrm{C} \\
\text { (for grade } \mathrm{F} \text { ) and }-40{ }^{\circ} \mathrm{C} \\
\text { (for grade } \mathrm{E} \text { ), } \mathrm{mm}^{\mathrm{c}}\end{array}$} & \multicolumn{2}{|c|}{$\begin{array}{l}\text { Nil-ductility transition } \\
\text { temperature (NDT), }{ }^{\circ} \mathrm{C}\end{array}$} \\
\hline & & & & & & & $\begin{array}{l}\text { Thickness up } \\
\text { to } 30 \mathrm{~mm}\end{array}$ & $\begin{array}{l}\text { Thickness up } \\
\text { to } 40 \mathrm{~mm}\end{array}$ \\
\hline RMRS & $610-770$ & 500 & 18 & 80 & $\leq-33$ & $\geq 0.20$ & -50 & -60 \\
\hline $\begin{array}{l}\text { European and American } \\
\text { classification societies }^{d}\end{array}$ & $610-770$ & 500 & 18 & $50^{e} 33^{f}$ & - & $\geq 0.15^{g} \geq 0.13^{h}$ & - & \\
\hline
\end{tabular}

${ }^{\mathrm{a} G O S T}$ R 52927-2008 for transverse specimen

${ }^{\mathrm{b}}$ Russian Maritime Register of Shipbuilding (RMRS) $\mathrm{Tkb}=1.1 \mathrm{~T} d+10^{\circ} \mathrm{C}$

${ }^{\mathrm{C}} \mathrm{RMRS}$ par.3.2.3.2

${ }^{d}$ EN ISO 19902, Det Norske Veritas, Bureau Veritas, and other

e In longitudinal direction to the rolling; according to DNV OS B101 2009

fIn transverse direction to the rolling; according to DNV OS B101 2009

${ }^{9}$ DNV-OS-C401-2008

${ }^{\mathrm{h}} \mathrm{API}$ RP2Z

according to EN 10149-2 standard. Figure 1 shows the maximum permissible values of sulfur (a) and phosphorous (b) and the corresponding values in the studied steels.

It can be seen from Table 3 that the E500 steel, which is produced by TMCP, has a significantly lower amount of chromium, nickel, and copper than the F500W steels manufactured by QT method. The lower amount of alloying elements has a positive correlation with the steel price and with weldability. The weldability of steel is usually defined by the equivalent carbon content $\left(\mathrm{C}_{\text {eqv }}\right)$ and the critical metal parameter $\left(\mathrm{P}_{\mathrm{cm}}\right)$. These parameters are defined by the steel's chemical composition and calculated using the following formulas (EN 1011; Ito and Bessyo 1968):

$$
\begin{aligned}
\mathrm{C}_{\text {eqv }}= & \mathrm{C}+\frac{\mathrm{Mn}}{6}+\frac{\mathrm{Cr}+\mathrm{Mo}+\mathrm{V}}{5} \\
& +\frac{\mathrm{Ni}+\mathrm{Cu}}{15} \\
\mathrm{P}_{\mathrm{cm}}= & \mathrm{C}+\frac{\mathrm{Si}}{30}+\frac{\mathrm{Mn}+\mathrm{Cu}+\mathrm{Cr}}{20} \\
& +\frac{\mathrm{Ni}}{60}+\frac{\mathrm{Mo}}{15}+\frac{\mathrm{V}}{10}+5 \mathrm{~B}
\end{aligned}
$$

The results of the calculations are shown in Table 4. It can be seen that the E500 TMCP steel has lower values for both $\mathrm{P}_{\mathrm{cm}}(0.19$ vs 0.22$)$ and $\mathrm{C}_{\text {eqv }}(0.41$ vs 0.46$)$ and it can therefore be considered as having better weldability properties. Additionally, it can be seen that the F500W steel manufactured from ingots has higher $\mathrm{C}_{\text {eqv }}$ than the F500W steel made from slabs.

\section{Microstructural analysis}

Microstructural analysis was performed using Zeiss Axiovert 40 MAT microscope with $\times 500$ magnification. All specimens for microstructural analysis, i.e., specimens of both the Finnish and Russian steels, were prepared according to GOST 5639. The resulting photos revealed that the E500 steel consists of 50 \% lath bainite, whereas in the F500W steel, the total share of lath bainite is less than $20 \%$. Higher lath bainite content contributes to the increase in strength of high-strength lowcarbon steel (Kong and Lan 2014). Tables 5 and 6 present images showing the microstructure and key metallurgical features of the steels.

\section{Mechanical properties}

To fulfill International and Russian standards (GOST R 52927-2008; ASTM E208; GOST 9454-78; GOST 149784; GOST 14019 80; GOST 2999-75; ASTM E112 13; ASTM E1382 - 97 2999; GOST 5639 82; BS 7448-1:1991; ISO 15653 2010; Russian Maritime Register of Shipping et al. 2012; EN ISO 19902 2007; DNV OS B101 2009; DNV OS C401 2010; API RP2Z:2005), the studied grades of high-strength steels must meet special requirements to be eligible for Arctic service, which are the following:

- Tensile strength $\left(\sigma_{\mathrm{t}}\right) 610-770 \mathrm{MPa}$

- Yield strength $\left(\sigma_{0.2}\right) \geq 500 \mathrm{MPa}$

- Elongation $\left(\delta_{5}\right) \geq 18 \%$

- Relative contraction ratio in thickness direction $(\Psi)>35 \%$

Table 3 Chemical composition of E500 and F500W steel plates, wt $\%$

\begin{tabular}{llllllllllllllll}
\hline Steel grade, plate thickness, and production method & $\mathrm{C}$ & $\mathrm{Si}$ & $\mathrm{Mn}$ & $\mathrm{S}$ & $\mathrm{P}$ & $\mathrm{Cr}$ & $\mathrm{Ni}$ & $\mathrm{Cu}$ & $\mathrm{Al}$ & $\mathrm{N}_{2}$ & $\mathrm{~V}$ & $\mathrm{Ti}$ & $\mathrm{Nb}$ & $\mathrm{Mo}$ \\
\hline E500, $25 \mathrm{~mm}$, TMCP & 0.08 & 0.25 & 1.50 & 0.001 & 0.008 & 0.05 & 0.90 & 0.15 & 0.053 & 0.003 & 0.008 & 0.018 & 0.035 & 0.013 \\
F500W, $30 \mathrm{~mm}$, QT & 0.09 & 0.29 & 0.65 & 0.001 & 0.006 & 1.18 & 1.96 & 0.35 & 0.030 & 0.006 & 0.004 & 0.003 & 0.025 & 0.122 \\
F500W, $35 \mathrm{~mm}$, QT & 0.09 & 0.24 & 0.65 & 0.002 & 0.006 & 0.48 & 1.28 & 0.61 & 0.020 & 0.008 & 0.010 & - & 0.029 & 0.190 \\
\hline
\end{tabular}



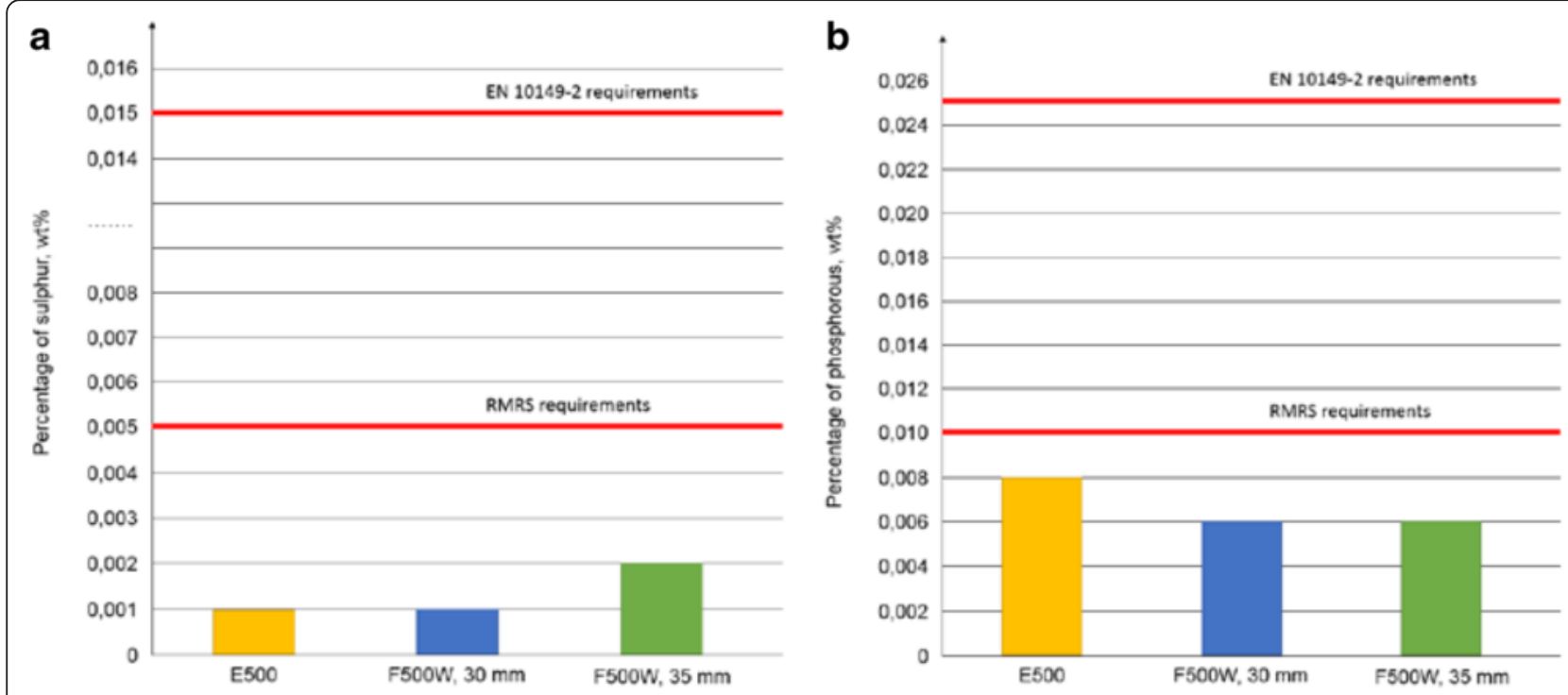

Fig. 1 Percentage of sulfur (a) and phosphorous (b) in E500 and F500W steel plates

Mechanical properties were determined by static tension tests of cylindrical samples and full-thickness tests. The static tensile tests were conducted to determine the ultimate tensile strength, maximum elongation, relative contraction ratio in thickness direction, and relative uniform elongation. Test specimens were prepared according to standard (GOST 1497-84): specimen type 3 no. 4. Figure 2 depicts the specimen preparation, and Table 7 presents results of the experiments.

The F500W steel plate of $30 \mathrm{~mm}$ thickness has higher values of $\sigma_{0.2}$ and $\sigma_{\mathrm{t}}$ than the other steel plates. The test results show a significant difference in the elongation $\delta_{5}$ values. Steel plate F500W of $30 \mathrm{~mm}$ thickness manufactured by QT has a $10 \%$ lower elongation value than E500 TMCP steel.

\section{Cold-resistant tests}

Cold resistance is a key characteristic of steels intended for Arctic applications. Poor cold resistance of the steel or welded joints can result in catastrophic failure caused by brittle fracture behavior of steel at low temperatures. Therefore, a comprehensive set of tests has been developed by standard societies to evaluate the cold-resistant properties of steels. This paper analyzes E500 and F500W steel plates using cold-resistant tests demanded by International and Russian standards: Charpy V-notch impact test, NDT, CTOD, and Tkb tests. The Tkb test is only required by Russian standards. The cold-resistant properties of E500 and F500W $(35 \mathrm{~mm})$ are mostly of interest, as the cold-resistant properties of F500W (30 $\mathrm{mm})$ were recently analyzed by another research group (Bashaev et al. 2014).

Charpy V-notch impact test The Charpy V-notch impact test is a standardized high strain-rate test that measures the amount of energy absorbed by a material during fracture at various temperatures. The Charpy test is an effective way to measure resistance to brittle fracture using small-scale impact samples and is suitable for the study of a fracture at low operational temperatures. In the current work, Charpy tests were conducted in the longitudinal direction at various temperatures within the temperature range of -100 to $+20{ }^{\circ} \mathrm{C}$. Figure 3 presents the results of Charpy tests and shows how the results correspond to the European and Russian requirements (GOST R 52927-2008; ASTM E208; Russian Maritime Register of Shipping et al. 2012). Each mark point in Fig. 3 is an average value for three measurements.

European norms (DNV-OS-B101) require at least that the impact toughness of high-strength steels be at least $50 \mathrm{~J}$ in the longitudinal direction to the rolling and at least

Table $4 \mathrm{P}_{\mathrm{cm}}$ and $\mathrm{C}_{\text {eqv }}$ weldability parameters of E500 and F500W steel plates

\begin{tabular}{lllll}
\hline Steel grade, plate thickness, and production method & Starting billet & $P_{\mathrm{cm},} \%$ & $C_{\text {eqv, }} \%$ & Specific alloying content $C_{\text {eqv }}(\%) /$ plate thickness, mm \\
\hline E500, $25 \mathrm{~mm}$, TMCP & Slab & 0.19 & 0.41 & 0.016 \\
F500W, $30 \mathrm{~mm}$, QT & Ingot & 0.25 & 0.61 & 0.020 \\
F500W, $35 \mathrm{~mm}$, QT & Slab & 0.22 & 0.46 & 0.013 \\
\hline
\end{tabular}


Table 5 Microstructure of steel plates, magnification $\times 500$

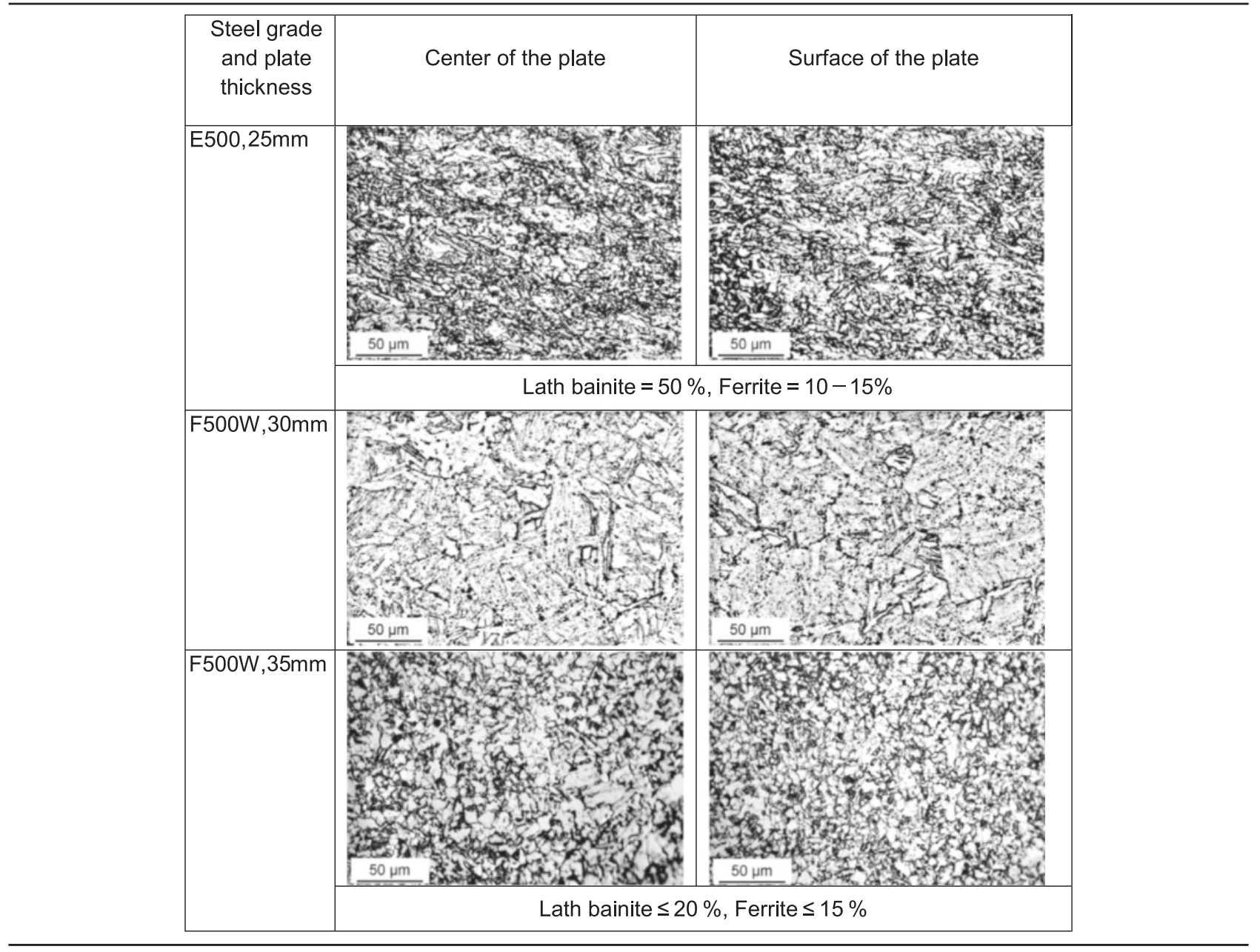

$33 \mathrm{~J}$ in the transverse direction to the rolling. At the same time, the Russian (RMRS) requirement for Charpy impact energy value is $80 \mathrm{~J}$ for the studied steel grades $\left(-40{ }^{\circ} \mathrm{C}\right.$ for E category steel and $-60{ }^{\circ} \mathrm{C}$ for $\mathrm{F}$ category steel) (Russian Maritime Register of Shipping et al. 2012). As can be seen from Fig. 3, the tested steel plates exhibit sufficiently high Charpy impact energy values at the temperatures studied; moreover, E500 steel can be used at $-60{ }^{\circ} \mathrm{C}$ and F500W steel can be utilized even at $-80{ }^{\circ} \mathrm{C}$. Table 8 shows the fracture surface of the Charpy specimens.

As it can be seen from Table 8, Charpy specimens were fractured in mostly ductile fracture mode, with small regions of brittle fractures. The impact toughness values are well above the minimum required values for both grades of steel. E500 steel fracture surface images reveal some brittle fracture regions.

NDT test The ductile-brittle transition temperature of a material represents the temperature at which the fracture energy passes below a predetermined point. The temperature above which a material is ductile and below which it is brittle is known as the nil-ductility transition (NDT) temperature. The NDT temperature point is important since once metal is cooled below that temperature, it has a greater tendency to fracture on impact instead of bending or deforming. The NDT test was performed using a vertical drop-testing machine K90 with an impact energy of $1350 \mathrm{~J}$ according to RMRS rules (Russian Maritime Register of Shipping et al. 2012) and ASTM E-208 standard (ASTM E208). Figure 4 shows test specimen dimensions, and Table 9 shows the results of the NDT test.

Results of the NDT test were evaluated according to ASTM E208. Specimens were marked as either fractured or non-fractured. Fractured specimens are specimens with a crack that propagates from the cladding metal to the base metal. Non-fractured specimens have a crack only in the cladding metal. Critical temperature NDT was determined as the highest temperature, with an interval of $5{ }^{\circ} \mathrm{C}$, at which at least one specimen fractured. The results of the NDT tests are given in Table 9. 
Table 6 Microstructural features

\begin{tabular}{|c|c|c|}
\hline $\begin{array}{l}\text { Steel grade } \\
\text { and plate } \\
\text { thickness }\end{array}$ & \multicolumn{2}{|c|}{ Microstructural features } \\
\hline E500, 25mm & 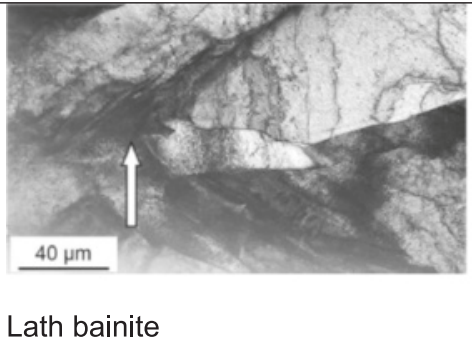 & Ferrite grain in the lath structure \\
\hline F500W, 35mm & Granular bainite & $\begin{array}{l}\text { W. } \\
\begin{array}{l}\text { Degenerate } \\
\text { carbides }\end{array}\end{array}$ \\
\hline
\end{tabular}

NDT test results show that both steels can be used at the studied temperatures. The F500W steel, however, can be used even at the much lower temperature of $-100{ }^{\circ} \mathrm{C}$. Figure 5 shows NDT specimens after testing.

Tkb test The Tkb test is a three-point bending test used to determine the temperature of ductile-to-brittle transition. This test is mostly used by the Russian industry and is required by RMRS rules. The Tkb temperature is determined by destroying a series of specimens at various temperatures and evaluating the percentage of brittle fracture on the fracture surface. The testing temperature which corresponds to $70 \%$ ductile fracture on the surface of the crack is the resulting temperature of the Tkb test (Russian Maritime Register of Shipping et al. 2012). The Tkb test according to RMRS rules (Russian Maritime Register of Shipping et al. 2012) and BS 7448 (BS 7448-1:1991) is performed on a specially shaped full-thickness specimen; geometrical dimensions of the specimen are shown in Fig. 6.

Tkb tests were performed on a universal testing machine Schenck PEZ-4371, and brittle fracture examination was done using a Philips electron microscope EM535. The percentage of ductile fracture was measured according to GOST 30456 97. Tkb tests results are shown in Table 10.

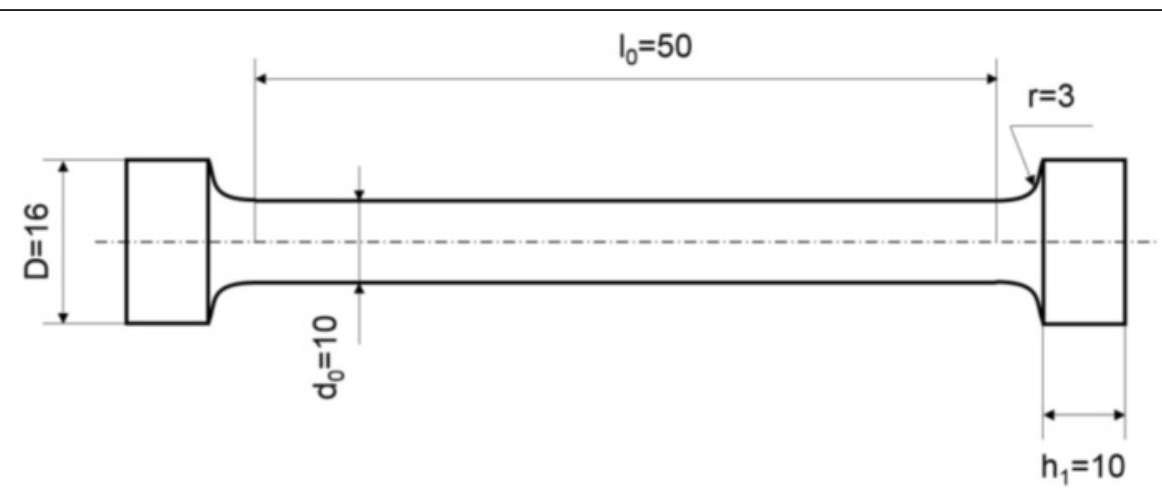

Fig. 2 Static tension test specimen, sizes are given in millimeters (GOST 1497-84) 
Table 7 Mechanical properties of E500 and F500W steels based on static tension tests of cylindrical samples

\begin{tabular}{|c|c|c|c|c|c|c|c|c|}
\hline \multirow{2}{*}{$\begin{array}{l}\text { Steel grade } \\
\text { and plate } \\
\text { thickness }\end{array}$} & \multicolumn{4}{|c|}{ Top of the sheet } & \multicolumn{4}{|c|}{ End of the sheet } \\
\hline & $\sigma_{\mathrm{t}}, \mathrm{MPa}$ & $\sigma_{0.2}, \mathrm{MPa}$ & $\delta_{5}, \%$ & $\psi, \%$ & $\sigma_{\mathrm{t}}, \mathrm{MPa}$ & $\sigma_{0.2}, \mathrm{MPa}$ & $\delta_{5}, \%$ & $\psi, \%$ \\
\hline $\mathrm{E} 500,25 \mathrm{~mm}$ & 635 & 550 & 24.0 & 67 & 620 & 515 & 27 & 73 \\
\hline F500W, $30 \mathrm{~mm}$ & 715 & 655 & 22.5 & 73 & 705 & 650 & 21 & 78 \\
\hline F500W, $35 \mathrm{~mm}$ & 615 & 520 & 23.0 & 74 & 600 & 500 & 27 & 75 \\
\hline
\end{tabular}

$\sigma_{t}$ tensile strength, $\sigma_{0.2}$ yield strength, $\delta_{5}$ elongation, $\psi$ relative contraction ratio in thickness direction

Both tested steel plates, E500 and F500W, showed similar results. Tkb is a full-thickness test; therefore, similar E500 and F500W results are substantially different, and F500W performs significantly better, as it is $10 \mathrm{~mm}$ thicker.

Specimens after testing are shown in Fig. 7.

CTOD test The crack tip opening displacement (CTOD) test measures the resistance of a material to crack propagation. CTOD tests were conducted according to RMRS rules (Russian Maritime Register of Shipping et al. 2012) and BS 7448 P.1 (BS 7448-1:1991). Growth of fatigue cracking was assessed on a universal testing machine Schenck PEZ-4371 with $250-\mathrm{kN}$ load at a frequency of $5-8 \mathrm{~Hz}$. The total number of loading cycles for the specimens was at least 55000. Figures 8 and 9 show the full-thickness specimen design for the CTOD tests, and Table 11 presents the results of the test for the steel grades studied. Figure 9 shows the CTOD-testing process, which starts with cooling down the specimen to a few degrees below the testing temperature, e.g., if the intended testing temperature is $-60^{\circ} \mathrm{C}$, the specimen is cooled down to about $-62{ }^{\circ} \mathrm{C}$. The next step is the specimen assembly, placing it into the testing machine, and thermo gauge installation. Gauges are used for precise temperature control during testing. The test starts when the temperature of the specimen becomes equal to the intended test temperature. During the test, the obtained data is collected and recoded into the special software

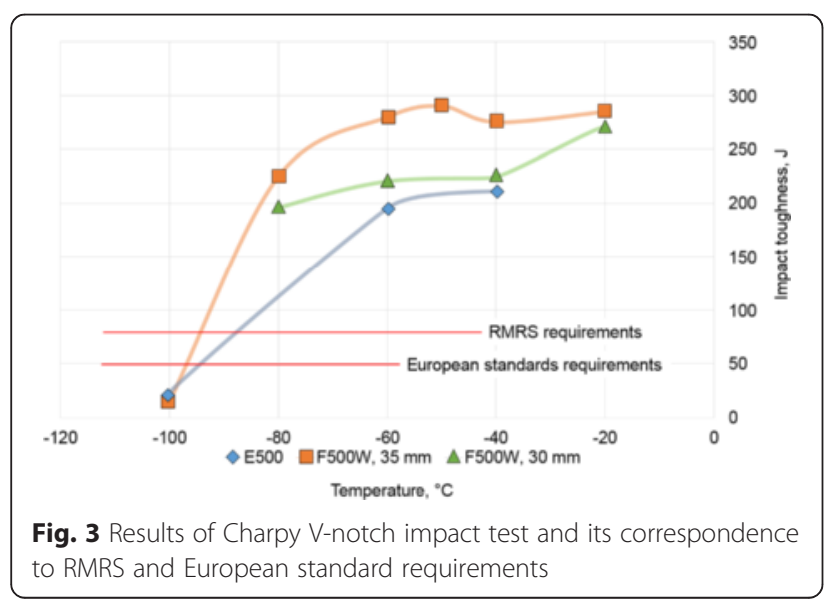

programme. The recoded data includes applied load, crack-tip opening displacement, load-line displacement and time.

CTOD test results at $-40{ }^{\circ} \mathrm{C}$ showed the superiority of the F500W steel plate made by QT method. RMRS rules (Russian Maritime Register of Shipping et al. 2012) set a required CTOD value for the tested steels in the range of $0.15-0.30 \mathrm{~mm}$, depending on the importance of the structural element and the loading conditions. Figure 10 shows test results plotted and compared with RMRS standard requirements. It can be seen that the E500 steel can be utilized only at temperatures higher than approximately $-55{ }^{\circ} \mathrm{C}$, since it does not satisfy RMRS standard requirements below that temperature.

\section{Welding joint evaluation}

Cold-resistant properties often reduced in welded highstrength steel joints. Most welding processes bring inevitable microstructural changes to the steels, which occur as a result of high heat input during welding. Microstructural changes in the weld are influenced by the steel alloying elements, the steel production method, and heat input, among other factors.

The microstructure of the heat-affected zone (HAZ) between the weld and the base metal varies continuously and is determined by the cooling rate, chemical composition and hardenability of the steel, the grain size and the degree of homogenization of the austenite carbon content, and alloying and microalloying elements before welding.

Major microstructural changes happen throughout the weld, which is divided into four zones (Fig. 11):

1. Grain growth zone or coarse-grained heat-affected zone (CGHAZ)

2. Recrystallized zone or fine grain heat-affected zone (FGHAZ)

3. Partially transformed zone or inter-critical heataffected zone (ICHAZ)

4. Tempering zone (warming up in the vicinity of $\mathrm{AC}_{1}$ temperatures)

The heating and the cooling rate during welding is dependent on several factors: the thickness of the metal, the welding current, the temperature of the metal to be 
Table 8 Fracture surface of Charpy specimens

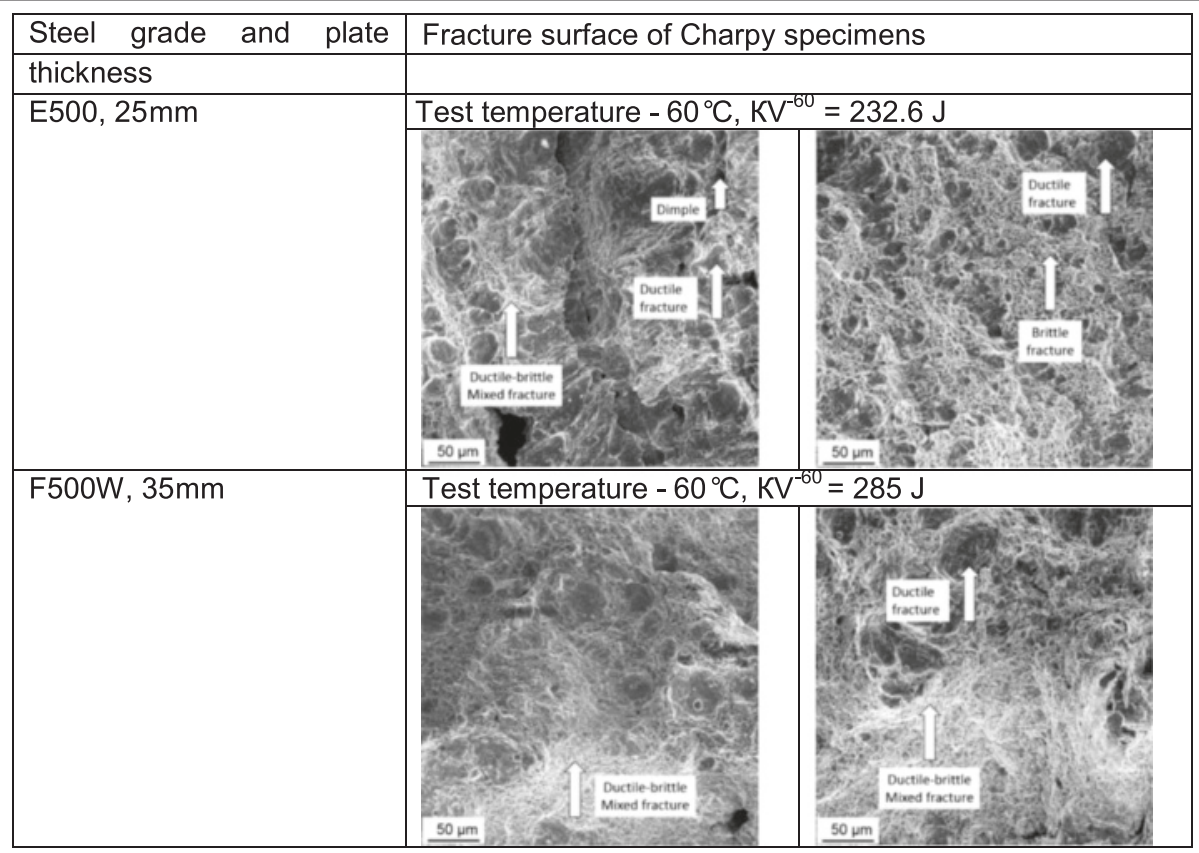

welded, the number of passes in the welding, and the welding heat input. Each of the above factors, individually and combined, can significantly affect the formation of microstructures in each of the four designated zones of the HAZ.

Welding experiments conducted as a part of the comparison of the E500 and F500W steel plates were carried out using a number of different welding processes. Steel plates were welded to form butt joints. The following welding methods and welding consumables were used for the E500 plate:

- Manual metal arc (MMA) welding-welding electrodes: ESAB OK 75.75, diameter of $4 \mathrm{~mm}$.

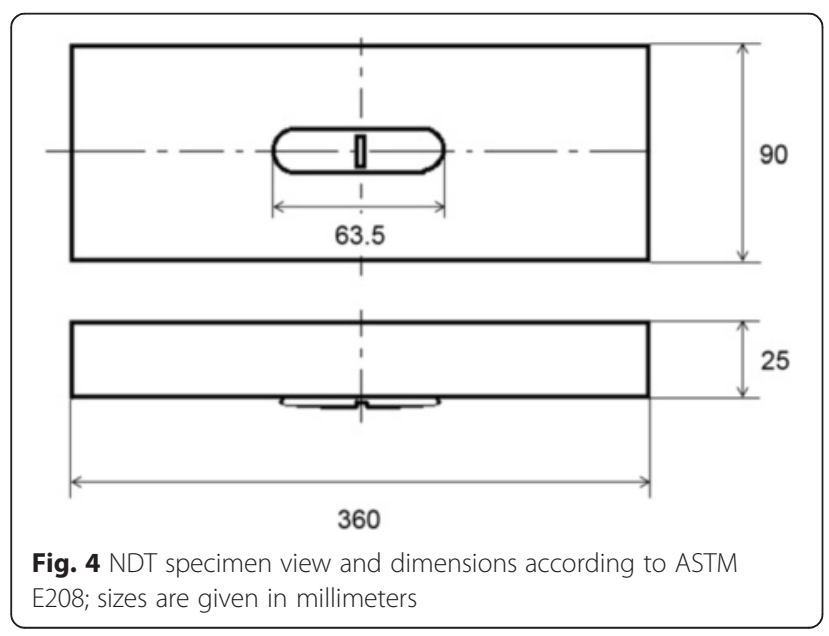

- Semi-automatic flux-cored arc welding (FCAW)-flux-cored wire: ESAB Tubrod 15.27, diameter $1.2 \mathrm{~mm}$.

- Submerged arc welding (SAW) - welding wire: Sv10GNA, diameter $4 \mathrm{~mm}$, and flux: ESAB OK 10.62.

The following welding methods and welding consumables were used for the F500W plate $(35 \mathrm{~mm}$ thickness only):

- Semi-automatic metal inert/active gas (MIG/MAG) welding-wire: Megafil 550R (EN 17632-A: T 556 Mn1Ni P M $1 \mathrm{H} 5$ ), diameter $1.2 \mathrm{~mm}$. Gas mixture:

Table 9 Results of NDT tests

\begin{tabular}{llll}
\hline $\begin{array}{l}\text { Steel grade and } \\
\text { plate thickness }\end{array}$ & Temperature, ${ }^{\circ} \mathrm{C}$ & Type of fracture & $\begin{array}{l}\text { Critical temperature } \\
\text { NDT, }{ }^{\circ} \mathrm{C}\end{array}$ \\
\hline E500, 25 mm & -70 & Fractured & -65 \\
& -65 & Fractured & \\
-55 & Non-fractured \\
-60 & Non-fractured \\
& -60 & Non-fractured \\
& -60 & Non-fractured \\
F500W, 35 mm & -65 & Non-fractured -100 \\
& -80 & Non-fractured \\
& -95 & Non-fractured \\
-95 & Non-fractured \\
& -95 & Non-fractured \\
& & Fractured \\
\hline
\end{tabular}




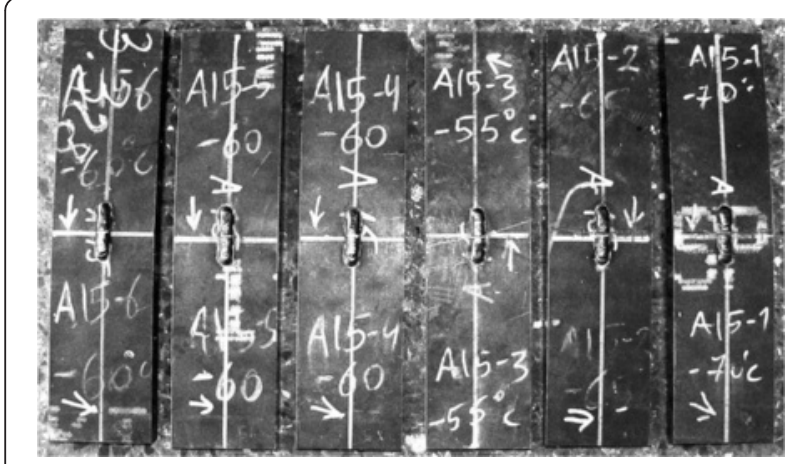

Fig. 5 NDT specimens after testing

$80 \% \mathrm{Ar}$ and $20 \% \mathrm{CO}_{2}$. Welding parameters: voltage-26 V; current-230 A; wire-feed speed-8.5 m/ $\min$

- SAW-welding wire: Sv-10GNA (diameter $4 \mathrm{~mm}$ ) and flux 48AF-60.

The chemical composition of the weld metal is presented in Table 12. It can be seen that the E500 weld metal has a significantly higher amount of alloying elements, such as $\mathrm{Mn}, \mathrm{Ni}$, and $\mathrm{Cr}$, which come from the MMA and FCAW welding consumables. The chemical composition of the E500 and F500W steel welds welded by SAW are almost identical.

After the welding process, specimens were prepared for mechanical tests. Mechanical properties of the weld metal are presented in Table 13.

E500 steels welded by MMA show extremely high values of ultimate tensile strength (up to $915 \mathrm{MPa}$ ) and yield strength (up to $849 \mathrm{MPa}$ ) along with low elongation values (as low as $14 \%$ ). The increase in tensile and yield strength can be explained by the high manganese content in the MMA welds (1.92\%) (Evans 1980).

A Vickers hardness test $\left(\mathrm{HV}_{5}\right)$ of the welded samples was performed. Hardness was measured in three lines parallel to the plate surface in the transverse direction. The first line is $2-3 \mathrm{~mm}$ below the surface of the steel plate, the second line is the central line of the weld, and

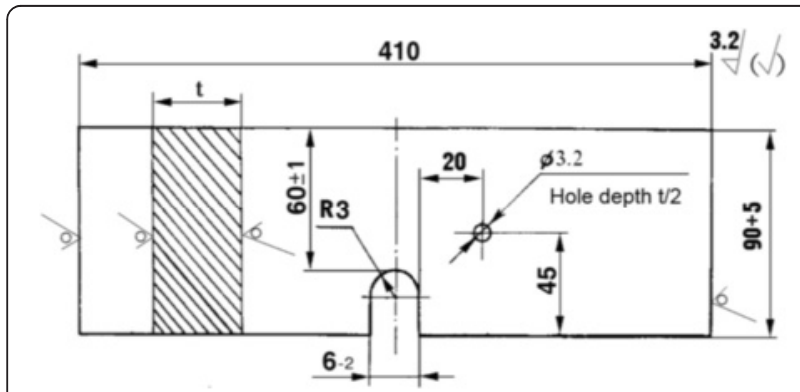

Fig. 6 Drawing of Tkb test specimen, sizes are given in millimeters (Russian Maritime Register of Shipping et al. 2012)
Table 10 Results of Tkb tests

\begin{tabular}{llll}
\hline $\begin{array}{l}\text { Steel grade and } \\
\text { plate thickness }\end{array}$ & Temperature, ${ }^{\circ} \mathrm{C}$ & Ductile fracture, \% & $\begin{array}{l}\text { Temperature } \\
\mathrm{Tkb},{ }^{\circ} \mathrm{C}\end{array}$ \\
\hline E500, $25 \mathrm{~mm}$ & +20 & 100 & -40 \\
& -35 & 78 & \\
-35 & 67 & \\
-40 & 72 & \\
-40 & 75 & \\
-40 & 67 & \\
-45 & 71 & -38 \\
-45 & 57 & \\
-60 & 42 & \\
-40 & 70 & \\
-40 & 65 & \\
-35 & 74 & \\
-25 & -25 & 90 & \\
-10 & 97 &
\end{tabular}

Ductile fracture percentage values, which are on the borderline of the test requitements $(70 \%)$ are highlighted in italics

the third line is located on the same distance from the central line as the first line, but in the opposite direction. Welds are shown in Fig. 12, and hardness test results are presented in Table 14.

As can be seen from Table 14, hardness does not exceed $350 \mathrm{HV}$; therefore, the welds meet the hardness requirements of the standard (ISO 9015; GOST 2999-75).

The cold-resistant properties of the welded joints were assessed by Charpy V-notch impact tests and CTOD

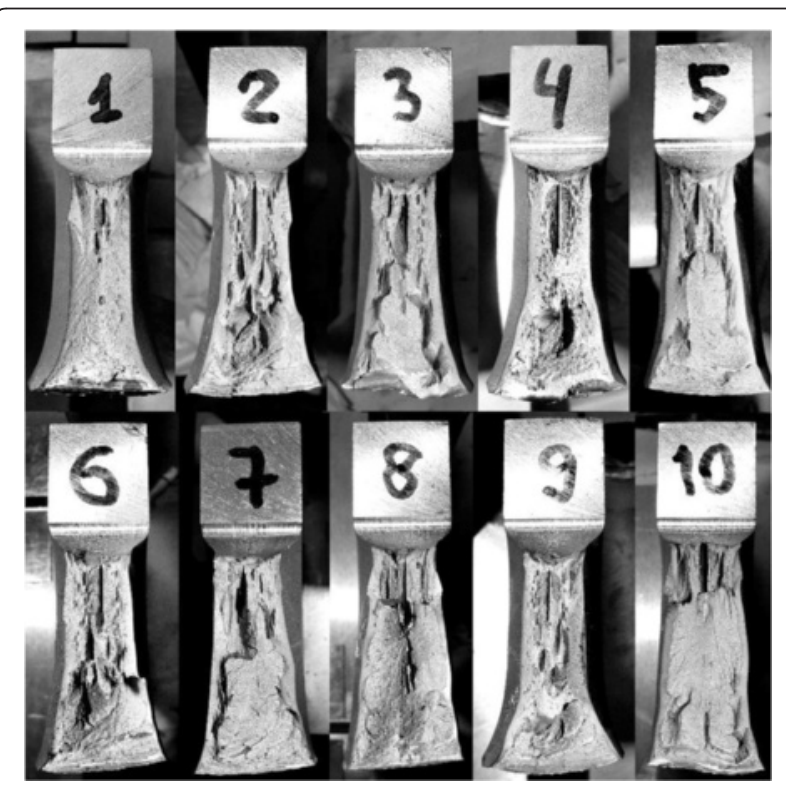

Fig. $7 \mathrm{Tkb}$ specimens after testing 


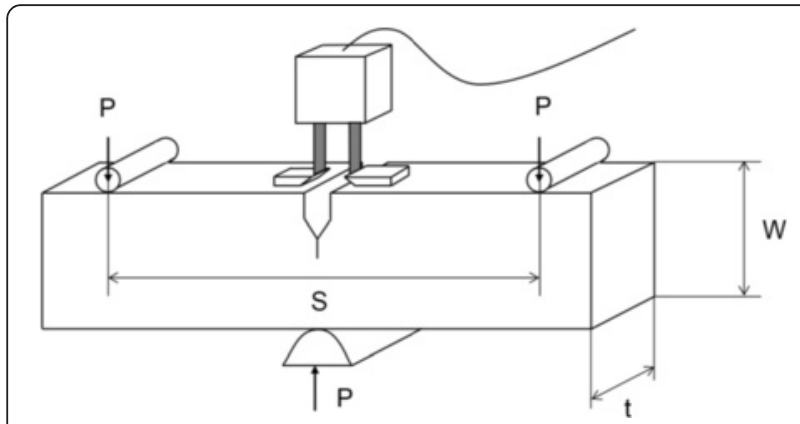

Fig. 8 Specimen for CTOD test, where $P$ is load, $B$ is steel plate thickness, $W=2{ }^{*} t ; S=9.2 * t$, sizes are given in millimeters (BS 7448-1:1991)

tests. The results of the Charpy V-notch impact tests are presented in Fig. 13 and Table 15.

CTOD tests of welded metal E500 (according to standard BS 7448 (BS 7448-1:1991)) with a notch on the fusion line were conducted, and the average result was found to be $19 \mathrm{~mm}$ at $-40{ }^{\circ} \mathrm{C}$ (Table 16).

\section{Results and discussion}

This research work assessed E500 TMCP and F500W QT steels and their welds based on International and Russian Arctic service requirements and proves that these steels can be utilized successfully for the specified temperature range. Additionally, the research presents data that can help to define limiting factors for steel's cold resistance and what standard requirements it might fail to fulfill. Russian standards have stricter requirements for cold-resistant properties of steels, therefore limiting the use of foreign-made steel in Russia.
Base metal chemical composition The E500 TMCP steel has a substantially lower amount of chromium, nickel, and copper compared to the F500W QT steels. Clearly, low amounts of chromium, nickel, and copper make the steel production cheaper and ease the welding process. The E500 TMCP steel has lower values for both parameters, which define weldability: $\mathrm{P}_{\mathrm{cm}}(0.19$ vs 0.22$)$ and $\mathrm{C}_{\text {eqv }}$ (0.41 vs 0.46$)$. However, specific alloying content (\%) over the plate thickness is even smaller for F500W $35 \mathrm{~mm}$ (0.013) compared to E500 (0.016). These numbers might explain better the F500W $35-\mathrm{mm}$ welding performance. That is not the case with the ingotmade F500W $30 \mathrm{~mm}(0.020)$.

Base metal microstructural analysis The microstructural scans revealed that the E500 steel consists of $50 \%$ lath bainite. The F500W steel has a total share of lath bainite less than $20 \%$. Higher lath bainite content contributes to the increase in strength of high-strength lowcarbon steel, which can be confirmed with mechanical tests: E500 tensile strength is $635 \mathrm{MPa}$ and yield strength is $550 \mathrm{MPa}$, which is larger than corresponding values for F500W $35 \mathrm{~mm}$ : 615 and $520 \mathrm{MPa}$, respectively.

Base metal mechanical properties The F500W steel plate of $30 \mathrm{~mm}$ thickness has higher values of $\sigma_{0.2}$ and $\sigma_{\mathrm{t}}$ than E500 and F500W $35 \mathrm{~mm}$. The test results also reveal significant difference in the elongation $\delta_{5}$ values; they are ranging from 21 to $27 \%$. Steel plate F500W of $30 \mathrm{~mm}$ thickness manufactured by QT has a $10 \%$ lower elongation value than E500 TMCP steel.

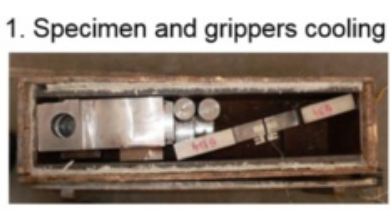

3. Experimental process

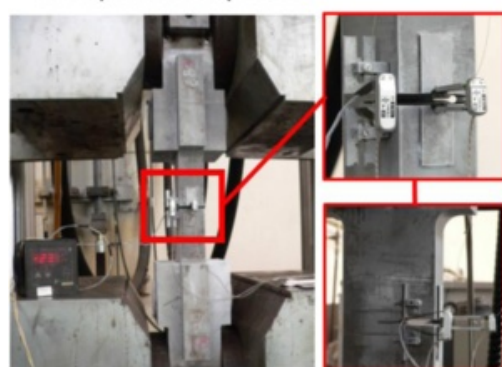

2. Assembling of specimen with grippers

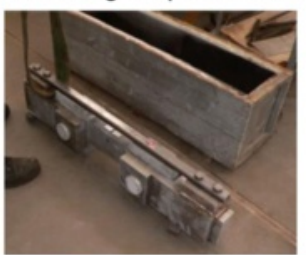

4. Experimental data collection

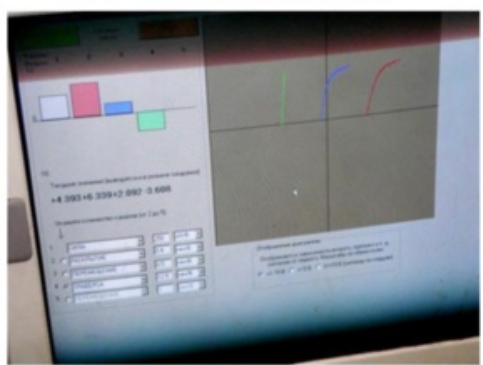

Fig. 9 CTOD test procedure for SENT specimens 
Table 11 CTOD testing of the base metal

\begin{tabular}{lllll}
\hline $\begin{array}{l}\text { Steel grade and } \\
\text { plate thickness }\end{array} \mathrm{mm}^{-40}$, & $\begin{array}{l}\mathrm{CTOD}^{-50}, \\
\mathrm{~mm}\end{array}$ & $\begin{array}{l}\mathrm{CTOD}^{-60}, \\
\mathrm{~mm}\end{array}$ & $\begin{array}{l}\mathrm{CTOD}^{-70}, \\
\mathrm{~mm}\end{array}$ \\
\hline E500, $25 \mathrm{~mm}$ & 0.60 & 0.50 & 0.10 & - \\
F500W, $30 \mathrm{~mm}$ & 0.73 & - & 0.94 & 0.71 \\
F500W, $35 \mathrm{~mm}$ & 1.18 & - & - & - \\
\hline
\end{tabular}

Base metal cold-resistant tests: Charpy V-notch impact test Cold resistance of the steel or welded joints is a key factor to guarantee robust steel performance at low temperatures and avoid failure caused by brittle fracture behavior. Charpy test is a simple and practical way to measure resistance to brittle fracture using small-scale impact samples. In the current work, Charpy tests were conducted in the longitudinal direction at various temperatures within the temperature range of -100 to $+20{ }^{\circ} \mathrm{C}$. The tested steel plates exhibit sufficiently high Charpy impact energy values at the temperatures studied; moreover, E500 steel can be used at $-60{ }^{\circ} \mathrm{C}$ and F500W steel can be utilized even at $-80{ }^{\circ} \mathrm{C}$. This is important, because some standards require the design temperature to be lower than the actual ambient temperature for $20{ }^{\circ} \mathrm{C}$ or even $30{ }^{\circ} \mathrm{C}$. Most Charpy specimens were fractured in the ductile fracture mode, containing small regions of brittle fractures. The impact toughness values are well above the minimum required values for both grades of steel. E500 steel fracture surface images reveal some brittle fracture regions.

Base metal cold-resistant tests: NDT test NDT test results show that both steels can be used at the studied temperatures. The E500 steel can be utilized to as low as $-60{ }^{\circ} \mathrm{C}$ and the F500W steel can be used even at the much lower temperature of $-100{ }^{\circ} \mathrm{C}$.

Base metal cold-resistant tests: Tkb test Both tested steel plates, E500 and F500W, showed similar values: $-40{ }^{\circ} \mathrm{C}$ for $\mathrm{E} 500$ and $-38{ }^{\circ} \mathrm{C}$ for $\mathrm{F} 500 \mathrm{~W}$. However, as

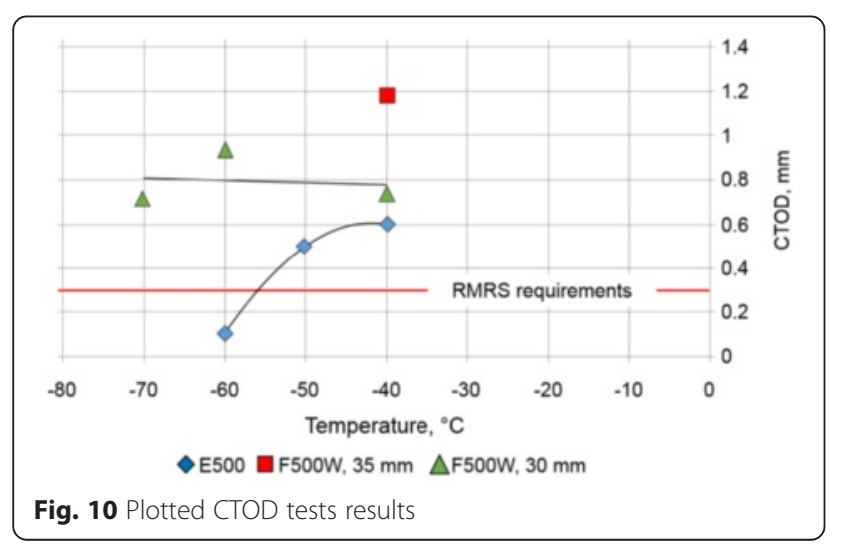

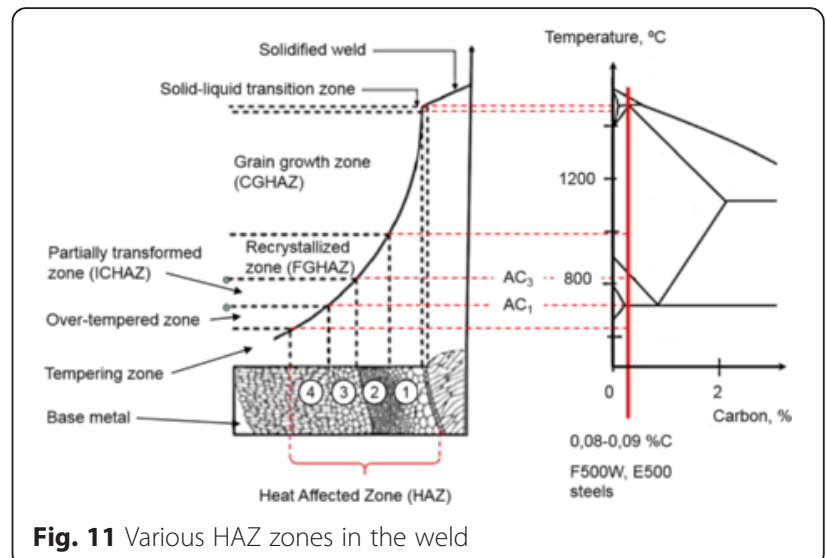

Tkb is a full-thickness test; therefore, the similar E500 and F500W test results are indicating that the $35-\mathrm{mm}$ thick F500W performs significantly better than $25-\mathrm{mm}$ E500 steel.

Base metal cold-resistant tests: CTOD test CTOD full-thickness test results at $-40{ }^{\circ} \mathrm{C}$ showed the superiority of the F500W steel plate made by QT method. RMRS rules set a required CTOD value for the tested steels in the range of at least $0.15-0.30 \mathrm{~mm}$, depending on the importance of the structural element and the loading conditions. The E500 steel can be utilized only at temperatures higher than approximately $-55{ }^{\circ} \mathrm{C}$, since it does not satisfy RMRS standards requirements below that temperature.

Overall, base metal cold-resistant tests showed that the E500 steel plate manufactured by TMCP method showed slightly lower values of cold resistance compared with the F500W steel plate; however, noticeable differences could be observed in special tests, such as NDT $\left(-100{ }^{\circ} \mathrm{C}>-65{ }^{\circ} \mathrm{C}\right)$ and CTOD (CTOD $-40{ }^{\circ} \mathrm{C}$ average $1.18 \mathrm{~mm}>0.41 \mathrm{~mm})$.

The next step of the research study is the welding performance tests. Welding tests indicated that generally both steels can be used for Arctic service. The E500 steel was welded by MMA, FCAW, and SAW, whereas F500W 35-mm steel was welded by MIG/MAG and SAW.

Welding joint chemical composition The E500 weld metal has a significantly higher amount of alloying elements, such as $\mathrm{Mn}, \mathrm{Ni}$, and $\mathrm{Cr}$, which come from the MMA and FCAW welding consumables. The chemical composition of the E500 and F500W steel welds welded by SAW is almost identical.

Welding joint mechanical properties E500 steels welded by MMA show extremely high values of ultimate tensile strength (up to $915 \mathrm{MPa}$ ) and yield strength (up 
Table 12 Chemical composition of E500 and F500W weld metal

\begin{tabular}{|c|c|c|c|c|c|c|c|c|c|c|}
\hline \multirow{2}{*}{$\begin{array}{l}\text { Steel grade } \\
\text { and plate } \\
\text { thickness }\end{array}$} & \multirow{2}{*}{$\begin{array}{l}\text { Welding } \\
\text { process }\end{array}$} & \multicolumn{9}{|c|}{ Amount of alloying elements in the weld, wt. \% } \\
\hline & & C & $\mathrm{Si}$ & $\mathrm{Mn}$ & $\mathrm{Ni}$ & $\mathrm{Cr}$ & $\mathrm{Cu}$ & Mo & S & P \\
\hline \multirow[t]{3}{*}{$\mathrm{E} 500,25 \mathrm{~mm}$} & MMA & 0.07 & 0.37 & 1.92 & 2.32 & 0.29 & 0.10 & 0.27 & 0.012 & 0.013 \\
\hline & FCAW & 0.06 & 0.41 & 1.66 & 2.57 & 0.06 & - & - & 0.010 & 0.012 \\
\hline & SAW & 0.07 & 0.34 & 1.24 & 1.02 & 0.05 & 0.25 & - & 0.013 & 0.015 \\
\hline \multirow[t]{2}{*}{ F500W, $35 \mathrm{~mm}$} & MIG/MAG & 0.05 & 0.44 & 1.5 & 1.43 & - & - & - & 0.011 & 0.016 \\
\hline & SAW & 0.07 & 0.20 & 1.02 & 1.08 & - & - & - & 0.014 & 0.015 \\
\hline
\end{tabular}

to $849 \mathrm{MPa}$ ) along with low elongation values (as low as $14 \%)$. The increase in tensile and yield strengths can be explained by the high manganese content in the MMA welds $(1.92 \%)$.

Welding joint hardness measurement Weld hardness was measured in the base metal region, HAZ, fusion line region, and welded metal. The highest value was recorded in the E500 MMA fusion line, which was $348 \mathrm{HV}$. The other values are relatively low and do not exceed $350 \mathrm{HV}$ and, consequently, acceptable according to the requirements.

Welding joint cold-resistant tests: Charpy V-notch impact test The results of the Charpy V-notch tests showed that F500W steel has better impact values in most cases compared to E500. Both steels show the lowest impact test toughness values in the welded metal and fusion line regions. E500 welded metal impact toughness values in MMA and SAW welding are in the borderline of acceptable values $(47 \mathrm{~J})$ at $-40{ }^{\circ} \mathrm{C}$. Nevertheless, the average impact toughness values are still acceptable.

Welding joint cold-resistant tests: CTOD test CTOD tests of welded metal E500 with a notch on the fusion line were conducted, and the average result was found to be $19 \mathrm{~mm}$ at $-40{ }^{\circ} \mathrm{C}$. The results are on the borderline of applicability of E500 steel in Russia.
The TMCP fabrication method is significantly cheaper than QT, which results in a lower price for the E500 steel plate. However, in the case of special applications and special structural requirements, the selection of the steel grade has to be made bearing in mind the differences in cold-resistant properties found in this work and cannot be made solely based on economic considerations.

\section{Conclusions}

Based on the conducted experiments, the following conclusions can be drawn:

- Steel plates E500 (TMCP, 25 mm thickness, Rautaruukki Oy) and F500W (QT, 35 and $30 \mathrm{~mm}$ thickness, Severstal) meet International and Russian standard requirements for low-temperature applications. E500 TMCP steel has low alloying content, featuring Mn alloying (1.5\%). QT F500W steels are highly alloyed with $\mathrm{Cr}, \mathrm{Ni}$, and $\mathrm{Cu}$ to improve cold resistance. Additionally, it is microalloyed with Mo.

- F500W obtains better results in special tests like $\operatorname{NDT}\left(-100{ }^{\circ} \mathrm{C}\right.$ is better than $\left.-65^{\circ} \mathrm{C}\right)$ and CTOD (CTOD $-40{ }^{\circ} \mathrm{C}$ average $1.18 \mathrm{~mm}>0.41 \mathrm{~mm}$ ). Using quenching followed by high tempering enables possible operational temperatures down to $-70{ }^{\circ} \mathrm{C}$. However, the NDT test is required only in Russian standards.

Table 13 Mechanical properties of E500 and F500W welded metal

\begin{tabular}{|c|c|c|c|c|c|c|}
\hline Steel grade and plate thickness & Welding process & Heat input, $\mathrm{kJ} / \mathrm{mm}$ & $\sigma_{\mathrm{t}}, \mathrm{MPa}$ & $\sigma_{0.2}, \mathrm{MPa}$ & $\delta_{5}, \%$ & $\psi, \%$ \\
\hline \multirow[t]{3}{*}{ E500, $25 \mathrm{~mm}$} & MMA & Not measured & $\begin{array}{l}908.4 \\
915.9 \\
875.4\end{array}$ & $\begin{array}{l}849.4 \\
821.2 \\
797.3\end{array}$ & $\begin{array}{l}14.6 \\
18.0 \\
16.7\end{array}$ & $\begin{array}{l}62.5 \\
65.1 \\
61.0\end{array}$ \\
\hline & FCAW & & $\begin{array}{l}790.9 \\
806.3 \\
833.1\end{array}$ & $\begin{array}{l}728.9 \\
751.3 \\
759.5\end{array}$ & $\begin{array}{l}20.9 \\
15.9 \\
18.4\end{array}$ & $\begin{array}{l}68.0 \\
68.2 \\
67.9\end{array}$ \\
\hline & SAW & & $\begin{array}{l}614.2 \\
614.6 \\
612.8\end{array}$ & $\begin{array}{l}514.0 \\
511.4 \\
497.8\end{array}$ & $\begin{array}{l}24.8 \\
24.6 \\
22.9\end{array}$ & \\
\hline \multirow[t]{2}{*}{ F500W, $35 \mathrm{~mm}$} & MIG/MAG & $3.0-3.5$ & 621.2 & 532.8 & 22.7 & 65.4 \\
\hline & SAW & $1.2-1.5$ & 622.6 & 562.1 & 23.3 & \\
\hline
\end{tabular}

For F500W steel, average values for the testing of three specimens are given in the table 


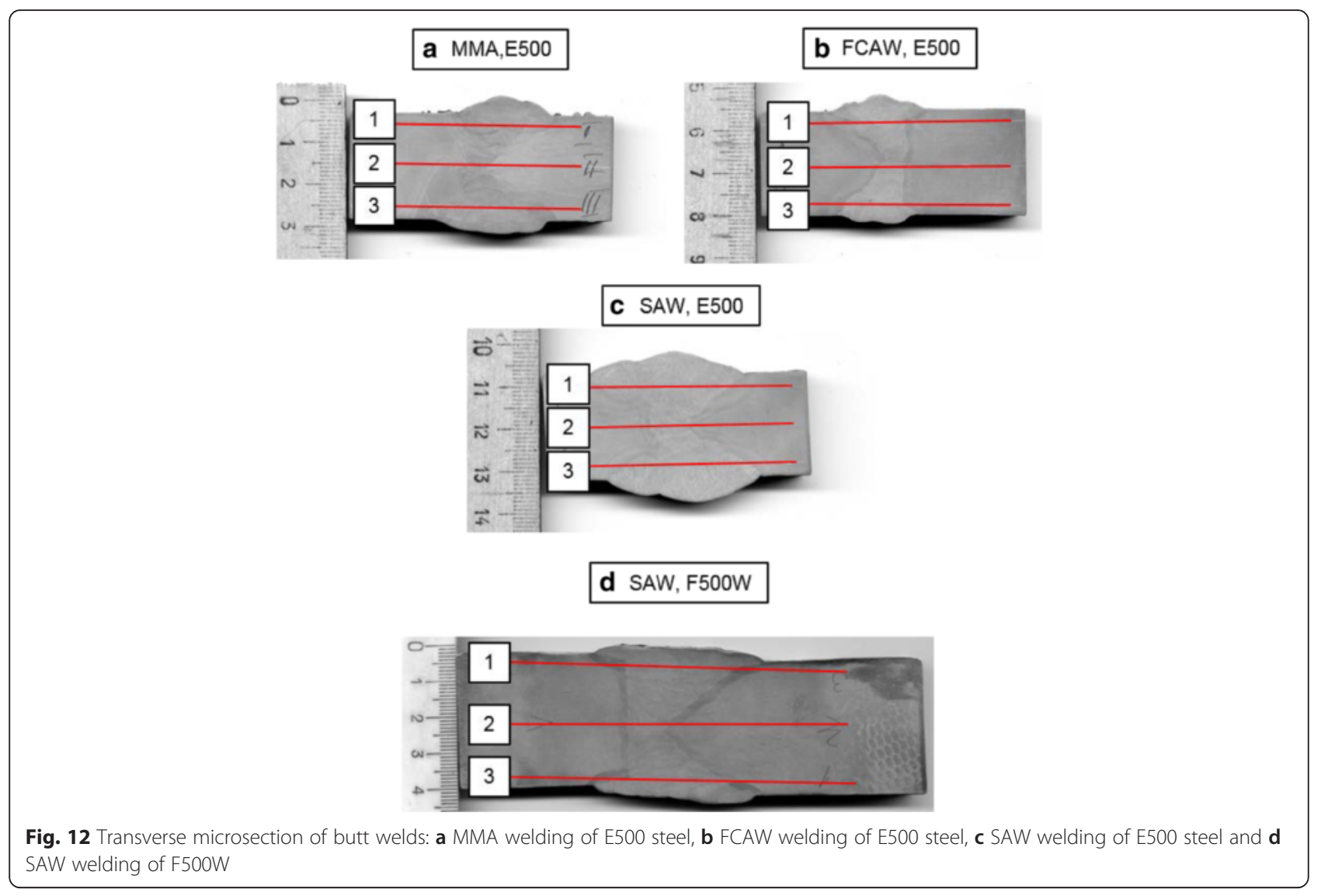

Table 14 Hardness of the welds

\begin{tabular}{|c|c|c|c|c|c|c|}
\hline \multirow{2}{*}{$\begin{array}{l}\text { Steel grade } \\
\text { and plate } \\
\text { thickness }\end{array}$} & \multirow{2}{*}{$\begin{array}{l}\text { Welding } \\
\text { process }\end{array}$} & \multirow[t]{2}{*}{ Line } & \multicolumn{4}{|l|}{ Hardness, $\mathrm{HV}_{5}$} \\
\hline & & & Base metal & HAZ & Fusion line & Welded meta \\
\hline \multirow[t]{10}{*}{$\mathrm{E} 500,25 \mathrm{~mm}$} & \multirow[t]{3}{*}{ MMA } & 1 & $255,254,250$ & $255,227,244,234,231,251$ & $309,348,317,279,279,293$ & $271,268,276$ \\
\hline & & 2 & $207,198,210$ & $268,273,254,233,247,238$ & $317,292,305,292,301,315$ & $309,303,283$ \\
\hline & & 3 & $213,218,211$ & $217,231,240,216,214,210$ & $276,274,268,258,260,245$ & $273,254,271$ \\
\hline & \multirow[t]{3}{*}{ FCAW } & 1 & $201,193,198$ & 219, 219, 214, 189, 201, 204 & $214,211,219,203,210,205$ & 204, 207, 197 \\
\hline & & 2 & $193,189,182$ & 227, 227, 227, 191, 197, 202 & $255,265,273,264,261,257$ & $271,274,273$ \\
\hline & & 3 & $202,204,195$ & $214,210,221,218,216,217$ & $210,212,206,214,202,210$ & $205,208,204$ \\
\hline & \multirow[t]{4}{*}{ SAW } & 1 & $207,214,202$ & $225,224,225,244,236,244$ & 293, 297, 299, 305, 307, 297 & $295,290,301$ \\
\hline & & 2 & $198,199,195$ & $228,211,245,248,240,212$ & $261,273,271,271,251,258$ & $284,288,265$ \\
\hline & & 3 & $206,207,210$ & $274,284,254,255,278,290$ & $303,311,290,286,251,271$ & $313,301,303$ \\
\hline & & & Hardness, $\mathrm{HV}_{10}$ & & & \\
\hline \multirow[t]{6}{*}{ F500W, $35 \mathrm{~mm}$} & \multirow[t]{3}{*}{ MIG/MAG } & 1 & $210,229,211,210$ & $264,248,249,201,261,261$ & - & $202,202,210$ \\
\hline & & 2 & 190, 192, 220, 202 & $239,226,256,227,263,233$ & - & $214,225,225$ \\
\hline & & 3 & $199,203,205,198$ & $236,242,227,271,284,273$ & - & $203,209,212$ \\
\hline & \multirow[t]{3}{*}{ SAW } & 1 & 189, 201, 206, 209 & $237,242,224,251,265,237$ & - & $209,210,218$ \\
\hline & & 2 & 196, 199, 191, 198 & $207,211,206,228,229,212$ & - & $229,218,215$ \\
\hline & & 3 & $194,200,189,200$ & $229,232,228,237,238,245$ & - & 206, 205, 211 \\
\hline
\end{tabular}




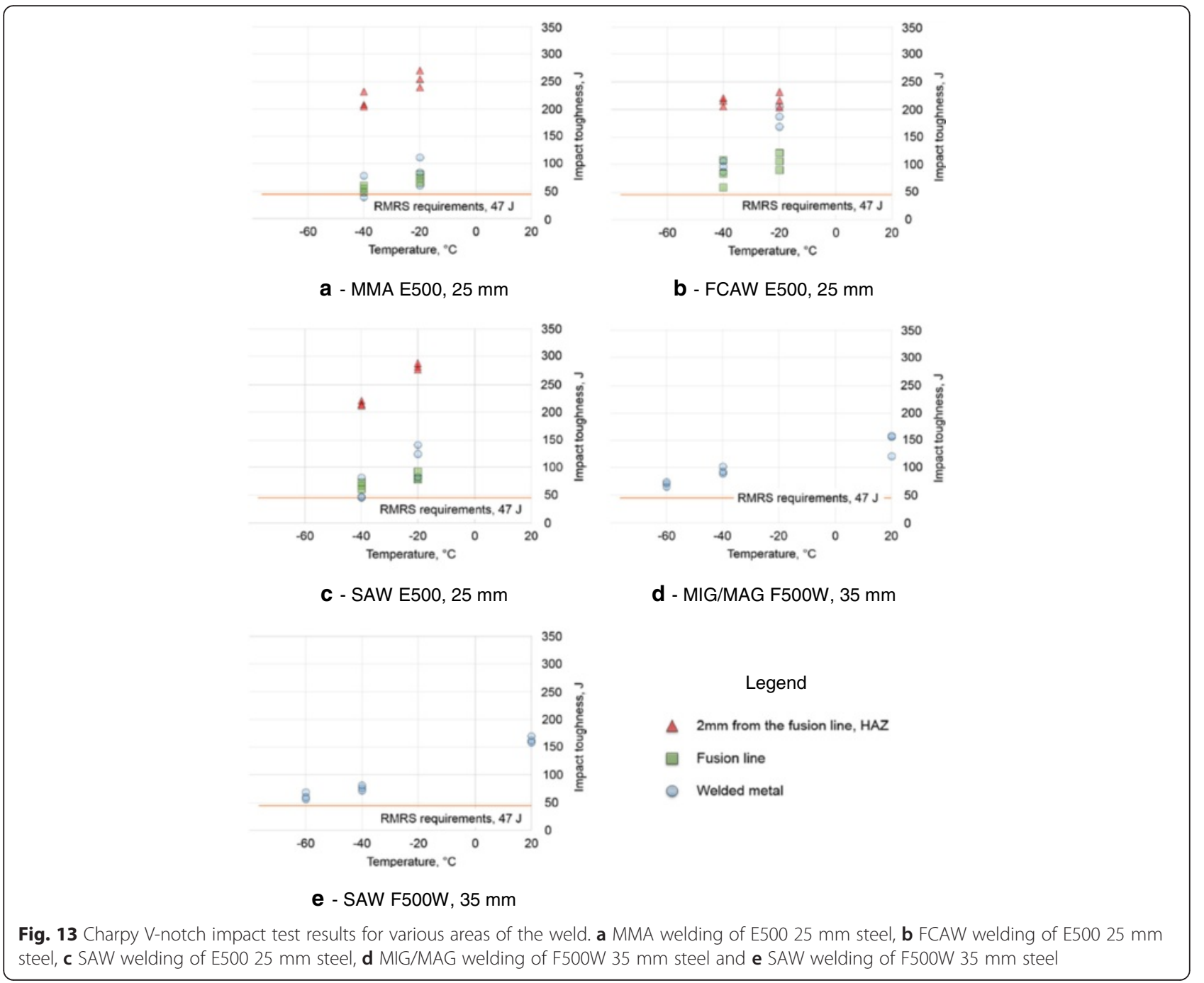

Table 15 Charpy $\vee$-notch impact test results for various areas of the weld

\begin{tabular}{|c|c|c|c|c|c|c|c|c|c|}
\hline \multirow{3}{*}{$\begin{array}{l}\text { Steel grade } \\
\text { and plate } \\
\text { thickness }\end{array}$} & \multirow{3}{*}{$\begin{array}{l}\text { Welding } \\
\text { process }\end{array}$} & \multicolumn{8}{|c|}{ Impact energy, J } \\
\hline & & \multirow{2}{*}{$\begin{array}{l}+20^{\circ} \mathrm{C} \\
\text { Welded metal }\end{array}$} & \multicolumn{3}{|l|}{$-20^{\circ} \mathrm{C}$} & \multicolumn{3}{|l|}{$-40^{\circ} \mathrm{C}$} & \multirow{2}{*}{$\begin{array}{l}-60{ }^{\circ} \mathrm{C} \\
\text { Welded metal }\end{array}$} \\
\hline & & & Welded metal & Fusion line & $\begin{array}{l}2 \mathrm{~mm} \text { from the } \\
\text { fusion line, HAZ }\end{array}$ & Welded metal & Fusion line & $\begin{array}{l}2 \mathrm{~mm} \text { from the } \\
\text { fusion line, } \mathrm{HAZ}\end{array}$ & \\
\hline \multirow[t]{3}{*}{$\mathrm{E} 500,25 \mathrm{~mm}$} & MMA & - & $\begin{array}{l}61.2 \\
85.3 \\
112.7\end{array}$ & $\begin{array}{l}66.2 \\
74.2 \\
81.9\end{array}$ & $\begin{array}{l}241.4 \\
256.8 \\
271.9\end{array}$ & $\begin{array}{l}39.5 \\
50.6 \\
79.7\end{array}$ & $\begin{array}{l}50.7 \\
56.7 \\
62.7\end{array}$ & $\begin{array}{l}207.9 \\
210.0 \\
234.0\end{array}$ & - \\
\hline & FCAW & - & $\begin{array}{l}170.9 \\
189.0 \\
206.8\end{array}$ & $\begin{array}{l}91.9 \\
108.3 \\
122.3\end{array}$ & $\begin{array}{l}206.3 \\
218.4 \\
233.8\end{array}$ & $\begin{array}{l}88.2 \\
98.0 \\
108.4\end{array}$ & $\begin{array}{l}60.5 \\
85.7 \\
110.9\end{array}$ & $\begin{array}{l}208.7 \\
218.1 \\
222.7\end{array}$ & - \\
\hline & SAW & - & $\begin{array}{l}86.8 \\
126.8 \\
143.4\end{array}$ & $\begin{array}{l}82.4 \\
83.2 \\
95.7\end{array}$ & $\begin{array}{l}277.5 \\
282.9 \\
288.3\end{array}$ & $\begin{array}{l}49.3 \\
47.6 \\
84.6\end{array}$ & $\begin{array}{l}63.4 \\
68.8 \\
74.5\end{array}$ & $\begin{array}{l}214.6 \\
216.3 \\
222.2\end{array}$ & - \\
\hline \multirow[t]{2}{*}{$\begin{array}{l}\text { F500W, } \\
35 \mathrm{~mm}\end{array}$} & MIG/MAG & $\begin{array}{l}123.5 \\
161.1 \\
159.7\end{array}$ & - & - & - & $\begin{array}{l}91.7 \\
95.3 \\
104.6\end{array}$ & - & - & $\begin{array}{l}67.1 \\
73.5 \\
76.6\end{array}$ \\
\hline & SAW & $\begin{array}{l}159.2 \\
163.0 \\
170.4\end{array}$ & - & - & - & $\begin{array}{l}74.3 \\
77.5 \\
82.8\end{array}$ & - & - & $\begin{array}{l}61.3 \\
61.6 \\
69.7\end{array}$ \\
\hline
\end{tabular}


Table 16 CTOD test results

\begin{tabular}{lll}
\hline Temperature, ${ }^{\circ} \mathrm{C}$ & CTOD value, $\mathrm{mm}$ & Average CTOD value, $\mathrm{mm}$ \\
\hline-20 & 0.08 & 0.46 \\
& 0.09 & \\
& 0.94 & \\
& 1.17 & \\
& 0.04 & \\
& 0.08 & 0.19 \\
-40 & 0.05 & \\
& 0.43 & \\
& 0.21 & \\
\hline
\end{tabular}

- E500 steel base metal tests showed applicability based on criteria of the Charpy test at temperatures as low as $-85^{\circ} \mathrm{C}$; based on criteria of NDT at $-65^{\circ} \mathrm{C}$; based on Tkb criteria only at $-40{ }^{\circ} \mathrm{C}$; and CTOD test showed E500 applicability to as low as $-55^{\circ} \mathrm{C}$. E500 welding tests showed, that Charpy impact toughness values are limiting the use of MMA welds to $-20{ }^{\circ} \mathrm{C}$, and FCAW and SAW welds can be utilized with some limitations at $-40{ }^{\circ} \mathrm{C}$. CTOD of the welded joint showed that E500 applicability at $-40{ }^{\circ} \mathrm{C}$ is satisfactory just on the borderline of the standard requirements.

- E500 TMCP steel has a lower carbon equivalent than F500W QT steel and therefore better weldability properties; however, this paper does not provide identical welding procedures to enable an adequate comparison of steel-welding performance.

\section{Competing interests}

The authors declare that they have no competing interests.

\section{Authors' contributions}

$P L$ and VR conducted experiments and collected the data. PL wrote the paper and presented comparisons of steels. PK and JM are PL's scientific supervisors, who guided and supported this work and contributed with theirs expertise and advices. All authors read and approved the final manuscript.

\section{Author details}

${ }^{1}$ Laboratory of Welding Technology, Lappeenranta University of Technology, Lappeenranta, Finland. ${ }^{2}$ Central Research Institute of Structural Materials Prometey, Saint-Petersburg, Russia.

Received: 7 December 2015 Accepted: 21 March 2016

Published online: 14 April 2016

\section{References}

API RP2Z:2005. Preproduction qualification for steel plates for offshore structures, Fourth Edition

Arctic Materials Technologies Development (Arctic Development) http://iris.lut.fi/ academic-network/projects/arctic-materials-technologies-development. Accessed 5 December 2015

ASTM E112 - 13. Standard test methods for determining average grain size

ASTM E1382 - 97 (2010). Standard test methods for determining average grain size using semiautomatic and automatic image analysis

ASTM E208. Standard test method for conducting drop-weight test to determine nil-ductility transition temperature of ferritic steels
Bashaev, V. K., Sych, O. V., Motovilina, G. D., Ryabov, V. V., \& Gusev, M. A. (2014). Study of cold resistance of high-strength alloy steel with a guaranteed yield strength of $500 \mathrm{MPa}$. Scientific and technical collection of Russian Maritime Register of Shipping, 37, 29-38.

BS 7448-1:1991. Fracture mechanics toughness tests. Method for determination of Klc, critical CTOD and critical J values of metallic materials

DNV-OS-B101:2009. Metallic materials

DNV-OS-C401:2010. Fabrication and testing of offshore structures

EN 1011-2. Welding-recommendations for welding of metallic materials_Part 2: arc welding of ferritic steels, British Standards Institution, March 2001 AMD A1 Dec 2003

EN 10149-2. Hot-rolled flat products made of high yield strength steels for cold forming

EN ISO 19902:2007. Petroleum and natural gas industries—fixed steel offshore structures

Evans GM (1980). Effect of manganese on the microstructure and properties of all-weld-metal deposits. Welding Journal, 59(3), 67-75

GOST 1497-84. Metals. Methods of tension test

GOST 2999-75. Metals and alloys. Vickers hardness test by diamond pyramid GOST 14019-80. Metals. Methods of bend tests

GOST 30456-97. Metal production. Rolled steel and tubes. Methods of blow bending tests

GOST 5639-82. Steels and alloys. Methods for detection and determination of grain size

GOST 9454-78. Metals. Method for testing the impact strength at low, room and high temperature

GOST R 52927-2008. Rolled stock of normal, increased- and high-strength steel for shipbuilding. Specifications, 2008

Gusev, M. A. (2013). Examination of resistance to brittle and ductile fracture of highstrength steels using new procedures of mechanical testing. Lappeenranta, Finland: Proceedings of PDM Forum for Finland-Russia Collaboration, 25-26 April 2013.

ISO 15653:2010. Metallic materials - method of test for the determination of quasistatic fracture toughness of welds

ISO 9015. Destructive tests on welds in metallic materials - hardness testing

Ito $Y$ and Bessyo K (1968). Weldability formula of high strength steels related to heat affected zone cracking. Published by the International Institute of Welding, Doc IX-576-68

Kong X, Lan L, (2014) Optimization of mechanical properties of low carbon bainitic steel using TMCP and accelerated cooling, Procedia Engineering 81, 11th International Conference on Technology of Plasticity, ICTP 2014, 19-24 October 2014, Nagoya Congress Center, Nagoya, Japan, 114-119

Lee, C.-H., Shin, H.-S., \& Park, K.-T. (2012). Evaluation of high strength TMCP steel weld for use in cold regions. Journal of Constructional Steel Research, 74, 134-139.

Russian Maritime Register of Shipping, Rules for the classification, construction and equipment of mobile offshore platforms. Saint-Petersburg, Russia: Russian Maritime Register of Shipping; 2012

Shin, Y. T. Kang, S. W. \& Lee, H. W. (2006). Fracture characteristics of TMCP and QT steel weldments with respect to crack length. Materials Science and Engineering: A, 434(1-2), 365-371.

Yan, J.-B., Liew, J. Y. R., Zhang, M.-H., \& Wang, J.-Y. (2014). Mechanical properties of normal strength mild steel and high strength steel S690 in low temperature relevant to Arctic environment. Materials \& Design, 61, 150-159.

\section{Submit your manuscript to a SpringerOpen ${ }^{\circ}$ journal and benefit from:}

- Convenient online submission

- Rigorous peer review

- Immediate publication on acceptance

- Open access: articles freely available online

- High visibility within the field

- Retaining the copyright to your article

Submit your next manuscript at $>$ springeropen.com 